\title{
Chemical characteristics and limnology of Loskop Dam on the Olifants River (South Africa), in light of recent fish and crocodile mortalities
}

\author{
J Dabrowski ${ }^{1,2 *}$, PJ Oberholster ${ }^{1,3}$, JM Dabrowski ${ }^{2}$, J Le Brasseur ${ }^{4}$ and J Gieskes ${ }^{5}$ \\ 'Department of Paraclinical Sciences, Faculty of Veterinary Science, University of Pretoria, P/Bag X04, Onderstepoort 0110, South Africa \\ ${ }^{2}$ CSIR Natural Resources and the Environment, PO Box 395, Pretoria, 0001, South Africa \\ ${ }^{3}$ CSIR Natural Resources and the Environment, PO Box 320, Stellenbosch, 7599, South Africa \\ 458 Derby Rd. Kensington, Johannesburg, 2094, South Africa \\ ${ }^{5}$ Scripps Institution of Oceanography, 9500 Gilman Drive, La Jolla CA 92037-0218, USA
}

\begin{abstract}
A declining crocodile population and fish mortalities attributed to pansteatitis, along with increasing blooms of Microcystis aeruginosa and Ceratium hirundinella, have led to serious concerns about water quality in Loskop Dam, on the Olifants River, South Africa. Major impacts include acid mine drainage and eutrophication associated with sewage effluent. However, the specific causes of pansteatitis remain elusive. In 2011 the water chemistry and limnology of Loskop Dam were studied to determine factors that may be influencing aquatic ecosystem health. Long-term monitoring data collected by the Department of Water Affairs were analysed for trends using a seasonal Mann-Kendall trend test, and were used to determine the trophic state of Loskop Dam using the Carlson index. Multiple sites were sampled which showed the reservoir was heterogeneous with regard to nutrient concentrations, algal biomass and dissolved metals. Specifically, the transitional zone was characterised by frequent algal blooms, resulting in fluctuating dissolved oxygen (range $=2.1-14.5 \mathrm{mg} / \ell$ ) and $\mathrm{pH}$ (range $=7.35-10.59$ ) levels. Using total phosphorus, Secchi depth, and chlorophyll- $a$ concentrations, the trophic state of Loskop Dam was classified as meso- to eutrophic. Significant positive trends were observed in total $(\mathrm{Tau}=0.422)$ and dissolved inorganic $(\mathrm{Tau}=0.193)$ phosphorus. The reservoir showed a monomictic pattern of summer stratification (October to April) and holomictic winter circulation (June to July), with an increase in the depth and extent of anoxia in the hypolimnion when compared to previous research. Simultaneous elevated concentrations of manganese $(>370 \mu \mathrm{g} / \ell)$ and iron in nearbottom water samples coincided with hypolimnetic anoxia. Aluminium concentrations exceeded the target water quality range $(>10 \mu \mathrm{g} / \ell)$ during summer (December) in both surface and near-bottom water samples. We conclude that fish in Loskop Dam are periodically exposed to several physiological stressors including elevated ammonia, aluminium, iron and manganese and possibly hydrogen sulphide, as well as low dissolved oxygen. While these factors have never individually been linked to pansteatitis, their combined impacts have not been studied. To ensure the sustainability of Loskop Dam, catchment management plans must focus on reducing phosphorus inputs, and continue seeking treatment solutions for mine-water associated with abandoned and working coal mines.
\end{abstract}

Keywords: Loskop Dam, limnology, pansteatitis, eutrophication, Olifants River

\section{INTRODUCTION}

Loskop Dam was constructed in 1937 to supply irrigation water to downstream agricultural areas (Van Vuuren, 2008). The irrigation canal system, measuring $480 \mathrm{~km}$, was completed just over 10 years later, in 1948 . The system provides water to the Loskop Irrigation Board, which is the second largest irrigation area in South Africa, supplying 700 properties and covering an area of 16117 ha (Oberholster and Botha, 2011). The dam is located about $32 \mathrm{~km}$ south of the town of Groblersdal in Mpumalanga Province, and is surrounded by a nature reserve. The main inflow to Loskop Dam is the Olifants River, which has the Wilge and Klein Olifants Rivers as its main tributaries. From Loskop Dam, the Olifants River flows north-east through the Drakensberg mountain range, the Kruger National Park, and into Massingir Dam in Mozambique, before continuing to the Indian Ocean.

\footnotetext{
To whom all correspondence should be addressed.

+27 83 256-3159; fax: +27 12 841-3954;

e-mail: jdabrowskil@csir.co.za

Received 20 July 2012; accepted in revised form 20 August 2013.
}

Land uses in the upper Olifants River catchment that impact freshwater ecosystems include coal mining, power generation, industry, agriculture, and wastewater treatment works (WWTWs) associated with urban areas. Coal mining is a dominant activity and the Witbank-Highveld coalfield produces $81 \%$ of the coal in South Africa, thereby contributing significantly to the South African economy (DMR, 2009). One of the adverse impacts of coal mining is the production of acid mine drainage (AMD), which occurs when pyrite associated with coal-bearing units is oxidised by exposure to air and moisture, forming sulphuric acid $\left(\mathrm{H}_{2} \mathrm{SO}_{4}\right)$ (Pinetown et al., 2007). Acid mine water decanting from abandoned mines in the upper Olifants River catchment is characterised by low $\mathrm{pH}(<3)$, high sulphate $\left(\mathrm{SO}_{4}^{2-}\right)$ concentrations ( $>2000 \mathrm{mg} / \mathrm{\ell})$ and elevated aluminium (Al), iron $(\mathrm{Fe})$ and manganese $(\mathrm{Mn})$ concentrations (Bell et al., 2001; Bell et al., 2002; Vermeulen and Usher, 2006). The increased metal concentrations may be attenuated by the receiving water body through a number of processes, including absorption and adsorption by aquatic flora and fauna, thus entering the wood web. Research has shown that algae growing in the AMD-impacted Blesbokspruit (tributary of the Klipspruit) have elevated levels of $\mathrm{Al}, \mathrm{Fe}, \mathrm{Zn}, \mathrm{Cu}, \mathrm{Ni}, \mathrm{Mn}$ and $\mathrm{Pb}$ (Bell et al., 2002), and several trophic levels have shown evidence of $\mathrm{Al}$ and $\mathrm{Fe}$ bioaccumulation in Loskop Dam (Oberholster et al., 2012). 
Previous studies have reported concentrations of $\mathrm{Al}$ and $\mathrm{Cu}$ in the water in Loskop Dam that exceeded the target water quality ranges (TWQR) for ecosystem health (Oberholster et al., 2010) set by the Department of Water Affairs (DWAF, 1996a). Along with dissolved metals, another impact associated with extensive coal mining in the catchment is the ongoing increase in $\mathrm{SO}_{4}{ }^{2-}$ concentrations, which have risen more than 7-fold in Loskop Dam since the 1970's (De Villiers and Mkwelo, 2009). Nutrient enrichment in the form of inorganic nitrogen (mainly nitrate and nitrite) and phosphate (orthophosphate) has increased, resulting in eutrophication of the dam and subsequent algal blooms (Oberholster et al., 2010). While agricultural sources have not been eliminated, a major source of nutrients is thought to be the WWTWs in the catchment that, according to the latest Green Drop Report (DWA, 2011), are largely dysfunctional (to varying degrees), releasing partially treated or untreated sewage into water resources.

Serious concerns about water quality in Loskop Dam were raised in the mid-2000s when a number of environmental problems were reported. These events occurred at several trophic levels indicating wide-scale changes in the structure and function of the ecosystem. At the level of primary production, the cyanobacterium Microcystis aeruginosa and dinoflagellate Ceratium hirundinella, which have been present in the dam for many years (Butty et al., 1980), began reaching bloom proportions around 2007 (Coetzee, 2011). Mozambique tilapia (Oreochromis mossambicus) were the next trophic level affected, with seasonal (usually spring) die-offs of predominantly large $(>30 \mathrm{~cm})$ males occurring in the transitional zone of the dam. Early work conducted by veterinarians from the Faculty of Veterinary Science at the University of Pretoria confirmed that the fish had pansteatitis, a disease characterised by obesity and lipid peroxidation. Apart from these chronic fish die-offs, several large-scale fish kills also occurred with up to $14 \mathrm{t}$ of fish, predominantly rednose mudfish (Labeo rosae), dying in an event that lasted around 30 days in August 2007. This event was accompanied by a strong smell of hydrogen sulphide from the water and bubbling at the water surface (Coetzee, 2011). The top predator in the aquatic ecosystem was also affected. In 2005 the first Nile crocodile (Crocodylus niloticus) found in a poor condition was taken to the Faculty of Veterinary Science where it was diagnosed with pansteatitis. The problem has been ongoing since then, with a documented decline in the crocodile population at Loskop Dam to 6 individuals (Botha et al., 2011). During fieldwork for the current study, another crocodile was found weak and dying near the Kranspoortspruit inflow (pers. obs.) in April 2011, and was confirmed to have pansteatitis after post mortem examination at the Faculty of Veterinary Science section of Pathology, University of Pretoria.

The only other incidence of pansteatitis in wild animal populations in South Africa was reported further downstream, in the Olifants River gorge in the Kruger National Park, where over 180 crocodiles died and were diagnosed with the condition (Huchzermeyer et al., 2011). Since then the population has been in decline (Ferreira and Pienaar, 2011). The condition has also been reported in sharptooth catfish (Clarius gariepinus) at the same location (Huchzermeyer et al., 2011). The occurrence of the disease in two geographically distinct fish and crocodile populations on the same river is peculiar, especially as there have been no reports of the disease occurring between these locations. This suggests that there is something unique about the combined environmental impacts present at both locations, that are not present elsewhere on the Olifants River.

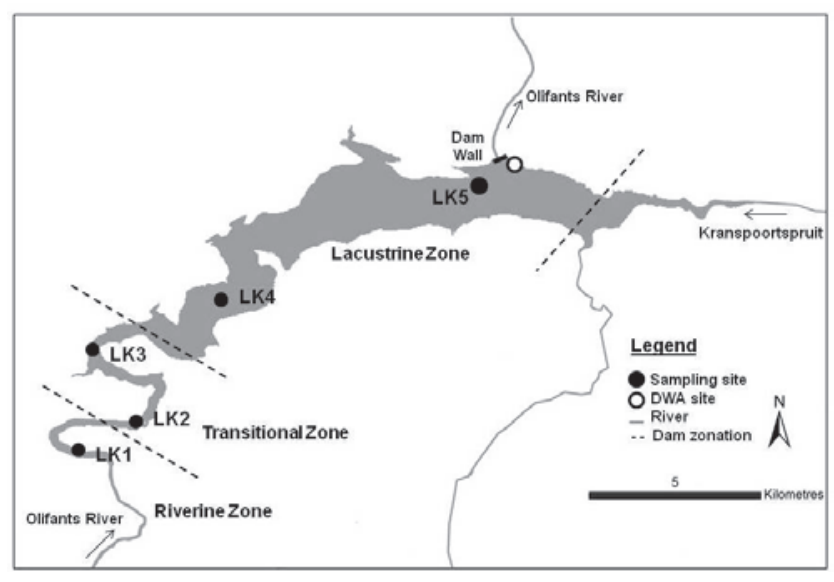

Figure 1

Map of Loskop Dam showing the location of 5 sampling sites and the Department of Water Affairs (DWA) site in various zones across the dam

Water quality impacts and their effects in Loskop Dam need to be well described and understood so that appropriate management strategies can be planned and prioritised. The last limnological surveys of Loskop Dam were completed several decades ago by Gieskes (1960) and Butty et al. (1980). Current information on limnology and water chemistry of the epilimnion and hypolimnion, including seasonal variations in Loskop Dam, is therefore required as a starting point to determine the physical and chemical processes that may be influencing water quality from an ecosystem health perspective.

The aetiology of pansteatitis in fish and crocodiles from Loskop Dam is as yet unknown, although it is recurrently described elsewhere as being related to a diet high in polyunsaturated fats and deficient in antioxidants, in captive-bred animals (Roberts et al., 1979; Larsen, 1983; Fytianou et al., 2006; Goodwin, 2006; Roberts and Agius, 2008). The diet of Oreochromis mossambicus in Loskop Dam was investigated during the present study, but these results will be reported separately. A thorough assessment of current water quality provided a backdrop to the dietary study, and was essential in understanding possible causes of fish kills, and pansteatitis in fish and crocodiles. The aims of this study were to assess:

- the current water chemistry and limnology of Loskop Dam over an annual cycle;

- the trophic state of Loskop Dam;

- time-series trends of physico-chemical data collected by the Department of Water Affairs (DWA) using a seasonal Mann-Kendall trend test; and

- water quality according to the DWAF guidelines for ecosystem health (DWAF, 1996a) where applicable.

\section{METHODS}

\section{Study site}

Loskop Dam ( $\left(5^{\circ} 26^{\prime} 57.05^{\prime \prime} \mathrm{S}, 29^{\circ} 19^{\prime} 44.36^{\prime \prime} \mathrm{E}\right)$ is in the Olifants Water Management Area (WMA). Vegetation in the upper Olifants River catchment consists of Highveld grassland in the upper reaches of the catchment and mixed bushveld and thornveld in the lower reaches around Loskop Dam (Mucina and Rutherford, 2006). Established study sites at 5 locations across the dam were sampled (Fig. 1). The sites were selected to reflect a spatial gradient across the dam from the riverine 
(LK1), through the transitional (LK2, LK3), to the lacustrine zone (LK4, LK5). The DWA water quality monitoring site (Station B3R002) is located near the dam wall and close to LK5 in the lacustrine zone (Fig. 1).

\section{Reservoir physiography}

Several reservoir attributes were revised as part of this study, as previous calculations of mean depth and mean retention time were completed in 1977 and 1978, prior to the dam wall being raised by $9 \mathrm{~m}$ in 1979 (Butty et al., 1980; Midgely et al., 1994). Mean annual runoff was calculated from the sum of annual flows recorded at DWA gauging stations B1HO15 (Klein Olifants River), B1H004 (Klipspruit), B1H010 (Olifants River), B1H002 (Spookspruit), and B2H015 (Wilge River). Only complete annual records (12 months) monitored simultaneously at all stations were included in the calculation. This limited the dataset to 14 years between 1994 and 2010. The mean retention time was calculated by dividing the mean annual runoff by the reservoir volume (Dodds and Whiles, 2010), and the mean depth was calculated by dividing lake volume by lake area (Timms, 2010). Shoreline length was obtained from the DWA Directorate of Spatial and Land Information Management. All other values in Table 1 were obtained from the DWA station catalogue (DWA, 2013). Shoreline development $\left(D_{L}\right)$ is an index that quantifies the irregularity of the shore. A perfect circle would have a $D_{L}$ value of 1 , with larger values indicating that the shoreline is more convoluted. The index was calculated as follows:

$$
\mathrm{D}_{\mathrm{L}}=\frac{L}{2 \sqrt{\pi A_{O}}}
$$

where:

$L$ is shoreline length $(\mathrm{km})$

$A_{O}$ is reservoir surface area $\left(\mathrm{km}^{2}\right)$.

Lakes with high shoreline development are often naturally more productive than those with low shoreline development (Dodds and Whiles, 2010).

\section{Current chemical characteristics}

\section{Surface water chemistry}

Loskop Dam was sampled on 5 occasions in 2011, during February, April, June, October and December, to cover seasonal variation in an annual cycle. One-litre integrated $(2 \mathrm{~m})$ water samples were collected using a plastic hose (diameter 5 $\mathrm{cm}$ ) lowered vertically into the water and then emptied into a plastic bucket and mixed prior to collecting the sample with a plastic container rinsed in water from the site. Samples were refrigerated at $4^{\circ} \mathrm{C}$ in the field and then frozen until they were delivered to the accredited CSIR Analytical Laboratory in Stellenbosch. Samples were filtered through $0.45 \mu \mathrm{m}$ pore size Whatman GF filters prior to being analysed for dissolved nutrients, metals and major ions using standard methods (APHA, 1998). Concentrations of Al, Fe, Mn, Se, V, Zn and $\mathrm{Cu}$ were determined using inductively coupled plasma mass spectrometry (ICP-MS). All major ions except chloride were analysed using inductively coupled plasma optical emission spectrometry (ICP-OES). Chloride and dissolved nitrogen and phosphorus were measured using a flow injection analyser (FIA). A $1-\ell$ sub-sample of water was collected from the bucket and stored at $4^{\circ} \mathrm{C}$ covered in foil for analysis of chlorophyll- $a$ concentrations. Samples were filtered using Whatman GF filters and then lyophilised. Chlorophyll- $a$ was extracted using $\mathrm{N}, \mathrm{N}$-dimethylformamide for $2 \mathrm{~h}$ at room temperature, then measured spectrophotometrically at $647 \mathrm{~nm}$ and $664 \mathrm{~nm}$ (Porra et al., 1989).

Field measurements of $\mathrm{pH}$, dissolved oxygen, conductivity, and temperature of the surface water were taken along with water transparency using a Secchi disc $(25 \mathrm{~cm})$ at each site. Measurements were made using a Hach HQ40D multiparameter meter using a pH gel intellical probe, luminescent dissolved oxygen intellical probe and a standard 4-pole graphite type electrical conductivity intellical probe (USEPA compliant).

\section{Near-bottom water chemistry and reservoir profiles}

Near-bottom water sampling was carried out at each site in Loskop Dam once during low flow (July 2011) and again during high flow (December 2011). A Van Dorn sampler was lowered to the last metre at each site and a sample of water was brought to the surface. Samples were analysed for concentrations of Al, $\mathrm{Fe}, \mathrm{Mn}, \mathrm{Si}$, nutrients, and $\mathrm{SO}_{4}{ }^{2-}$ using the methods described above. Because routine surface water sampling was not carried out in July, a surface water sample was collected simultaneously and analysed for the same constituents to serve as a comparison to the near-bottom samples. Vertical profiles of $\mathrm{pH}$, dissolved oxygen, conductivity and temperature were measured to a maximum depth of $30 \mathrm{~m}$ using the same meter at each site and each sampling period.

\section{Statistical analyses}

Water chemistry results were compared to target water quality ranges (TWQR), chronic effect values (CEV) and acute effect values (AEV), where applicable, as set out in the water quality guidelines for ecosystem health in South Africa (DWAF, 1996a). Molar ratios of $\mathrm{SO}_{4}{ }^{2-} / \mathrm{Cl}$ were calculated as an indicator of sulphate inputs of mining or industrial origin.

\section{Department of Water Affairs monitoring data}

\section{Trophic indicators}

The trophic status of Loskop Dam was determined using data collected between 1985 and 2011 from the DWA monitoring station. Trophic state index (TSI) values were determined using the Carlson (1977) method as follows:

$$
\begin{aligned}
& \text { TSI }(\mathrm{TP})=14.42(\ln \mathrm{TP})+4.15 \\
& \mathrm{TSI}(\mathrm{SD})=60-14.41(\ln \mathrm{SD}) \\
& \mathrm{TSI}(\mathrm{CHLA})=9.81(\ln \mathrm{CHLA})+30.6
\end{aligned}
$$

where:

TP is total phosphorus $(\mu \mathrm{g} / \ell)$

$\mathrm{SD}$ is Secchi-depth $(\mathrm{m})$

CHLA is chlorophyll- $a$ concentrations $(\mu \mathrm{g} / \ell)$

$\ln$ is the natural logarithm of the variable.

The annual median values for total phosphorus, Secchi-disk depth and chlorophyll- $a$ were used to calculate TSI values. Censored values were replaced at 0.5 times the detection limit and included in the calculation of annual medians. The DWA records occasionally included samples collected at various depths, but only surface and integrated $(5 \mathrm{~m})$ sample values were used in the calculations. 
The TSI was developed in order to determine the state of eutrophication of a water body, with phosphorus limitation as an underlying assumption. All three variables are meant to be normalised by the indices, allowing any of the three to describe the trophic state of a water body. A reservoir is considered oligotrophic (nutrient-poor) up to a TSI of 30, mesotrophic (moderate nutrients) up to a TSI of 50 and eutrophic (nutrientenriched) above 50 .

\section{Trend analysis}

Data compiled from the DWA monitoring station at Loskop Dam were analysed for increasing or decreasing trends using a nonparametric seasonal Mann-Kendall test (Hirsch et al., 1982) performed in XLSTAT version 2012.6.08 @ Addinsoft. The test removes seasonal effects that can obscure trends, does not require data to be normally distributed, and permits the use of censored values. The dataset was modified to include only surface and $5 \mathrm{~m}$ integrated samples. Sampling frequency was predominantly monthly, but varied randomly, so data were aggregated to a single value for 4 seasons each year using the median of the available data. The seasonal Mann-Kendall test was computed on each season individually and results were then combined to form an overall trend result. Multiple detection limits were common so censored data were re-censored to the highest detection limit. Trends for each parameter were only calculated if less than $50 \%$ of the data were censored and more than 5 years of data were available (Stevens, 2003). This meant that trends could not be analysed for several parameters, including dissolved oxygen, temperature, Secchi depth, orthophosphate and dissolved metals. The sodium adsorption ratio (SAR) was also included in the analysis due to the importance of Loskop Dam for irrigation. High SAR values indicate that water may not be suitable for irrigation as sodium replaces calcium and magnesium in the soil (DWAF, 1996b).

\begin{tabular}{|l|c|}
\hline \multicolumn{2}{|c|}{ TABLE 1 } \\
Attributes of Loskop Dam at full supply \\
level, and the upper catchment of the \\
Olifants River
\end{tabular}

\section{RESULTS}

\section{Reservoir physiography}

The revised attributes of Loskop Dam are presented in Table 1 . The revised mean retention time was 12.2 months, and the mean depth was $15.43 \mathrm{~m}$. The revised mean annual runoff was calculated as $323.31 \mathrm{Mm}^{3}$ which was substantially lower than $10780 \mathrm{Mm}^{3}$ (Midgely et al., 1994), but similar to $304.5 \mathrm{Mm}^{3}$ calculated by Butty et al. (1980). The shoreline development value of 3.96 was greater than 3 , which indicated that Loskop Dam had a highly irregular shoreline that could be described as dendritic or tree-shaped (Timms, 2010).

\section{Current chemical characteristics}

\section{Surface water chemistry}

A summary of the major water quality constituents measured in the upper $2 \mathrm{~m}$ at all 5 sites is presented in Table 2, and selected parameters are presented in boxplots (Fig. 2). For the duration of the study concentrations of $\mathrm{Se}, \mathrm{Zn}, \mathrm{V}$ and $\mathrm{Cu}$ were below analytical detection limits and were, therefore, not reported in detail.

Origins of patterns in water quality across the dam could
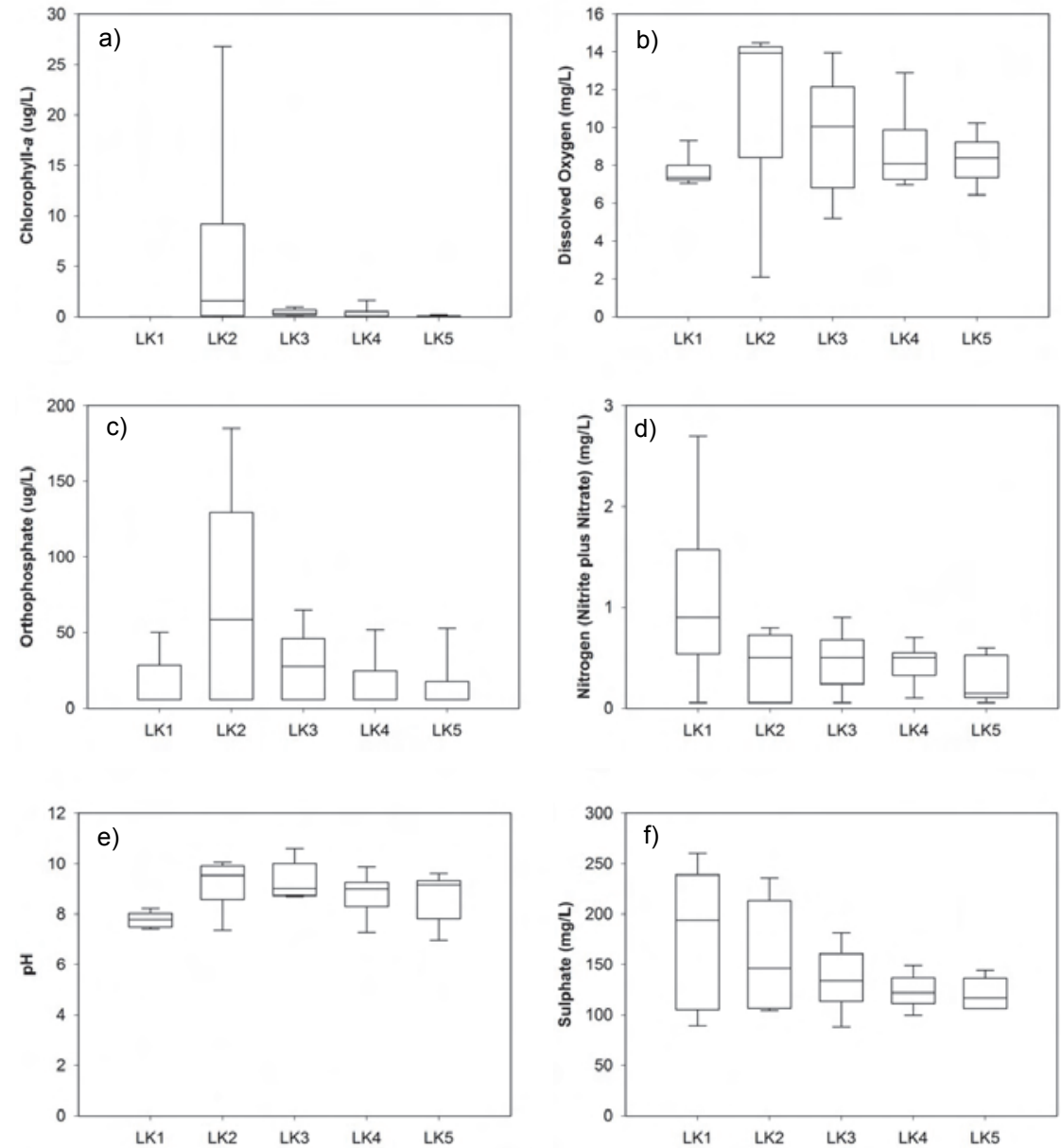

Figure 2

Boxplots of selected water quality constituents measured in $2 \mathrm{~m}$ integrated surface water samples $(n=5)$ from five sites in Loskop Dam during 2011. Plots are of the median (centre line), $10^{\text {th }}, 25^{\text {th }}$ (box), 75th, and $90^{\text {th }}$ (whiskers) percentiles. 
TABLE 2

Summary of constituents measured in $2 \mathrm{~m}$ integrated surface water samples from 5 sites in Loskop Dam during 2011

\begin{tabular}{|c|c|c|c|c|c|c|c|c|c|c|c|c|c|c|c|c|}
\hline$\stackrel{ \pm}{\infty}$ & ڤ્ّ & I & 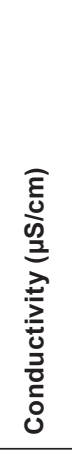 & 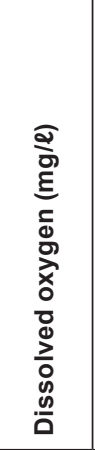 & 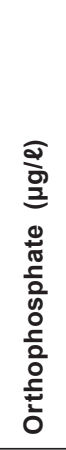 & 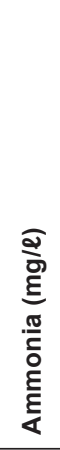 & 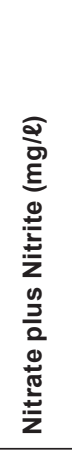 & 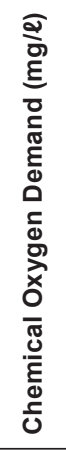 & 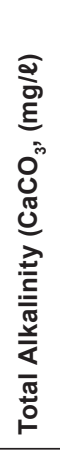 & 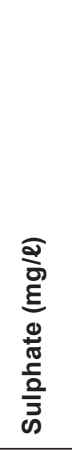 & 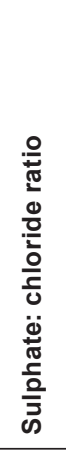 & 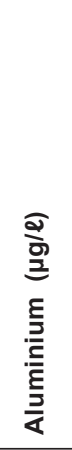 & 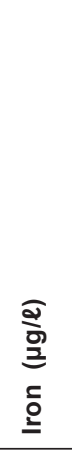 & 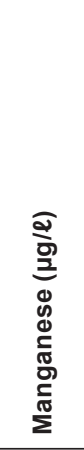 & 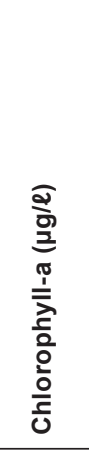 & 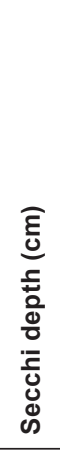 \\
\hline \multirow{5}{*}{ LK1 } & Feb & 7.95 & 372 & 7.30 & 2.1 & 0.1 & 0.7 & 5.7 & 53 & 110 & 6.6 & - & - & - & 0.006 & 49 \\
\hline & Apr & 7.79 & 329 & 7.56 & 50 & 0.2 & 0.9 & 51 & 46 & 89 & 5.8 & - & - & 103.4 & 0.01 & 42 \\
\hline & Jun & 7.51 & 503 & 9.33 & - & 0.2 & 2.7 & 10 & 25 & 194 & 9.6 & - & - & 220 & 0.002 & 279 \\
\hline & Oct & 7.40 & 643 & 7.37 & - & - & 1.2 & 20 & 33 & 260 & 10.1 & 2.9 & 2.4 & 2.0 & - & 169 \\
\hline & Dec & 8.22 & 654 & 7.05 & - & - & - & 33 & 53 & 232 & 7.7 & 17.5 & - & 4.2 & - & 95 \\
\hline \multirow{5}{*}{ LK2 } & Feb & 9.86 & 364 & 10.55 & 185 & - & - & 69 & 60 & 104 & 6.3 & - & - & 0.02 & 26.8 & 0 \\
\hline & Apr & 10.06 & 400 & 14.50 & 59 & - & 0.8 & 71 & 27 & 107 & 7.2 & - & - & 60 & 3.31 & 21 \\
\hline & Jun & 9.00 & 409 & 14.20 & 111 & 0.2 & 0.7 & 93 & 49 & 146 & 7.7 & - & - & 30 & 1.58 & 51 \\
\hline & Oct & 9.53 & 583 & 13.93 & - & - & 0.5 & 64 & 30 & 236 & 9.5 & 9.3 & 4.5 & 15.3 & 0.12 & 85 \\
\hline & Dec & 7.35 & 653 & 2.10 & - & 0.2 & - & 55 & 54 & 206 & 8.5 & 19 & 17.4 & 1 & 0.08 & 69 \\
\hline \multirow{5}{*}{ LK3 } & Feb & 10.59 & 364 & 10.05 & 39 & - & - & 23 & 51 & 88 & 6.2 & - & - & -- & 0.933 & 0 \\
\hline & Apr & 8.70 & 397 & 7.34 & 28 & 0.1 & 0.9 & 47 & 37 & 122 & 7.6 & $\underline{20}$ & 20 & 10 & 0.33 & 115 \\
\hline & Jun & 9.01 & 398 & 11.56 & 65 & - & 0.6 & 43 & 50 & 134 & 7.1 & - & - & 10 & 0.2 & 122 \\
\hline & Oct & 9.81 & 464 & 13.95 & - & - & 0.5 & 104 & 27 & 154 & 6.9 & 10.8 & 13 & 3.3 & 0.55 & 83 \\
\hline & Dec & 8.74 & 505 & 5.21 & - & - & 0.3 & 35 & 49 & 181 & 7.4 & 16.2 & 5.8 & 0.7 & 0.13 & 121 \\
\hline \multirow{5}{*}{ LK4 } & Feb & 9.87 & 363 & 12.89 & - & - & - & 34 & 48 & 100 & 6.4 & - & - & - & 1.63 & 81 \\
\hline & Apr & 9.06 & 385 & 8.09 & 16 & - & 0.4 & 75 & 45 & 115 & 7.3 & - & - & - & 0.14 & 170 \\
\hline & Jun & 7.26 & 400 & 6.98 & 52 & - & 0.7 & 23 & 52 & 133 & 7 & - & - & - & 0.07 & 284 \\
\hline & Oct & 8.64 & 426 & 8.87 & - & - & 0.5 & 16 & 42 & 122 & 6 & 3.9 & 3 & 4.3 & 0.02 & 405 \\
\hline & Dec & 8.99 & 456 & 7.37 & - & - & 0.5 & 22 & 41 & 149 & 6.9 & 11.4 & 3.9 & 0.4 & - & 374 \\
\hline \multirow{5}{*}{ LK5 } & Feb & 9.60 & 363 & 10.25 & - & - & 0.12 & 22 & 58 & 106 & 6.6 & - & - & - & 0.07 & 103 \\
\hline & Apr & 9.16 & 369 & 8.91 & - & - & 0.15 & 51 & 40 & 117 & 7.5 & - & 17 & - & 0.23 & 164 \\
\hline & Jun & 6.97 & 404 & 6.44 & 53 & 0.1 & 0.6 & 27 & 53 & 134 & 7.1 & - & - & 40 & 0.02 & 268 \\
\hline & Oct & 8.11 & 423 & 8.41 & - & - & - & 20 & 45 & 106 & 5.3 & - & 2.5 & 3.5 & - & 575 \\
\hline & Dec & 9.24 & 451 & 7.69 & - & - & 0.5 & 15 & 44 & 144 & 6.6 & 9.9 & - & 0.3 & - & 350 \\
\hline
\end{tabular}

-, values below detection limit; bold print, value exceeds TWQR; underline, value exceeds CEV

be broadly categorised as those influenced by cycles within the dam, and those influenced by the inflow of the Olifants River. Examples of parameters influenced by internal cycles are chlorophyll-a (Fig. 2a), dissolved oxygen (Fig. 2b), orthophosphate (Fig. 2c) and pH (Fig. 2e), all of which were linked to algal blooms, and peak in the transitional zone before decreasing across the dam to LK5.

Algal blooms were reflected by chlorophyll- $a$ concentrations which were highest in the transitional zone, especially at Site LK2, which peaked at $26.79 \mu \mathrm{g} / \ell$ in April (Table 2) during a bloom of $M$. aeruginosa. Secchi depths in this area were consistently $<100 \mathrm{~cm}$ and were always lower than at Site LK1, indicating that turbidity was of biological as opposed to mineral origins. In contrast, Secchi depth values ranged widely from $103 \mathrm{~cm}$ to $575 \mathrm{~cm}$ at LK5, with the highest values corresponding to non-detectable chlorophyll-a concentrations in a distinct clear water phase during October (Table 2). The $\mathrm{pH}$ at the inflow site (LK1) was generally in the neutral range of 7 to 8 , compared to the other sites where the $\mathrm{pH}$ was frequently above 9 (Fig. 2e). Dissolved oxygen levels also ranged widely in the transitional zone with values at LK2 peaking at $14.5 \mathrm{mg} / \ell$ in April and dropping to $2.1 \mathrm{mg} / \ell$ at the surface in December (Table 2). This coincided with the lowest observed concentration of chlorophyll- $a(0.08 \mu \mathrm{g} / \ell)$ and $\mathrm{pH}(7.35)$ at the site, indicating that oxygen depletion was probably due to the collapse of an algal bloom. Furthermore, the chemical oxygen demand was consistently highest at Sites LK2 and LK3 in the dam (Table 2).

Orthophosphate and inorganic nitrogen (nitrate plus nitrite) showed contrasting patterns across the sampling sites. Orthophosphate concentrations were highest in the transitional zone, measuring $185 \mu \mathrm{g} / \ell$ at Site LK2 in February, and indicated an internal source of phosphorus within the dam, fluctuating with the growth and collapse of algal blooms (Fig. 2c). Concentrations recorded in February, April and 
June at Site LK2 fell within the eutrophic range of 25-250 $\mu \mathrm{g} / \ell$ (DWAF, 1996a). Inorganic nitrogen concentrations were highest at the inflow site LK1 and decreased across the sites to the dam wall, indicating that the main source was the Olifants River (Fig. 2d). The highest concentration at Site LK1 was 2.7 $\mathrm{mg} / \ell$, measured in June, which fell within the eutrophic category of $>2.5 \mathrm{mg} / \ell$, while the remaining values fell within the mesotrophic range between 0.5 and $2.5 \mathrm{mg} / \ell$ (Table 2; DWAF, 1996a).

The inflow was also the main source of $\mathrm{SO}_{4}{ }^{2-}$ which was highest at Site LK1 measuring $260 \mathrm{mg} / \ell$ in October with a $\mathrm{SO}_{4}{ }^{2-} / \mathrm{Cl}$ ratio of 10.1 , and decreasing across the dam to LK5 where the highest measurement was $144 \mathrm{mg} / \ell$ in December. Dissolved Al concentrations exceeded the TWQR of $10 \mu \mathrm{g} / \ell$ (for $\mathrm{pH}>6.5$ ) during October at LK3, and during December at Sites LK1, LK2, LK3 and LK4. The highest Al concentration exceeded the CEV of $20 \mu \mathrm{g} / \ell$ (for $\mathrm{pH}>6.5$ ) at LK3 in April. Dissolved Mn only exceeded the TWQR of $180 \mu \mathrm{g} / \ell$ at Site LK1 in June (Table 2).

A noteworthy event occurred in June at the inflow site LK1 when the water was a milky-blue colour, which coincided with elevated conductivity $(503 \mu \mathrm{S} / \mathrm{cm})$, high $\mathrm{SO}_{4}{ }^{2-}$ concentrations $(194 \mathrm{mg} / \ell)$ and the highest observed Mn concentrations (220 $\mu \mathrm{g} / \ell$ ) at this site (Table 2).

\section{Near-bottom water chemistry and reservoir profiles}

Concentrations of inorganic and total nitrogen and phosphorus in near-bottom water were very similar to those measured at the surface at all sites, and therefore the results are not presented. Concentrations of dissolved $\mathrm{Al}, \mathrm{Fe}$ and $\mathrm{Mn}$ in the surface and near-bottom water at all sites are presented in Fig. 3. Profiles of temperature, dissolved oxygen, $\mathrm{pH}$ and conductivity are presented for Site LK2 (Fig. 4) and LK3 (Fig. 5) in the transitional zone, and Site

LK5 (Fig. 6) in the lacustrine zone. Site LK1 was omitted because it was well mixed without stratification, and LK4 was omitted because the conditions were very similar to LK5.

Dissolved Al, Fe and Mn measured at the inflow of the Olifants River (LK1) confirm the riverine conditions at this site, because they were approximately uniform from the surface to the bottom at a depth of $4 \mathrm{~m}$ in July, and $3 \mathrm{~m}$ in December 2011 (Fig. 3). No marked stratification of $\mathrm{pH}$, temperature, dissolved oxygen, or conductivity was observed at LK1; this was consistent with the well-mixed conditions associated with higher river flows and relatively shallow depth.

Dissolved $\mathrm{Al}, \mathrm{Fe}$ and $\mathrm{Mn}$ differed between surface and near-bottom depths on several occasions at the other sites. There was a clear seasonal difference in $\mathrm{Al}$ concentrations between July and December
(Fig. 3a). Aluminium exceeded the TWQR of $10 \mu \mathrm{g} / \ell$ at Sites LK1, LK2, LK3 and LK4 in the surface and near-bottom water during December. At Sites LK2 and LK5, Al exceeded the CEV of $20 \mu \mathrm{g} / \ell$ in the near-bottom water in December, which coincided with low oxygen levels at LK2 (1.38 mg/ $\ell$; Fig. 4b) and anoxic conditions $>10 \mathrm{~m}$ at LK5 (Fig. 6b). In July all recorded $\mathrm{Al}$ concentrations were within the TWQR.

Surface water concentrations of Mn were consistently within the TWQR at all sites except as already mentioned at LK1 in June. However, concentrations exceeded the CEV of $370 \mu \mathrm{g} / \ell$ in the near-bottom water at Sites LK3, LK4 and LK5
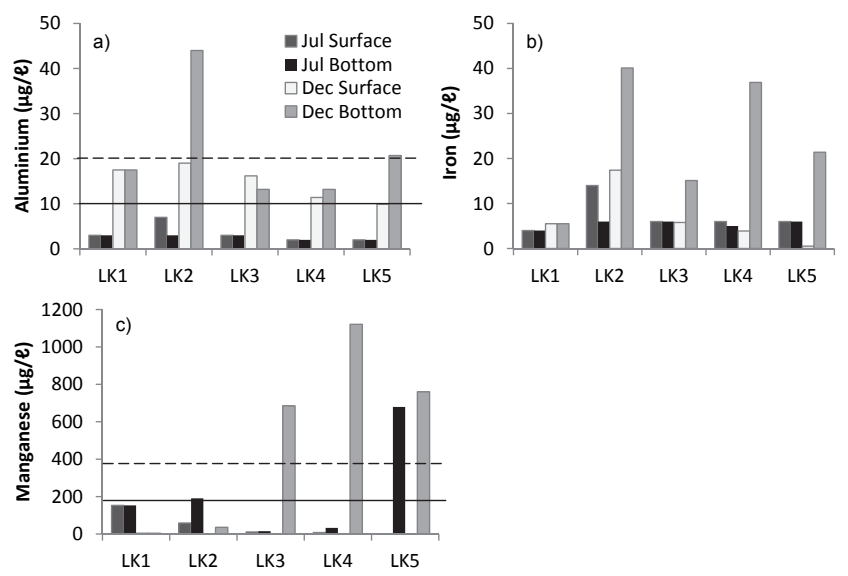

Figure 3

Surface and near-bottom concentrations of dissolved $\mathrm{Al}(\mathrm{a}), \mathrm{Fe}(\mathrm{b})$ and $\mathrm{Mn}$ (c) at five sites in Loskop Dam sampled during July and December 2011. Solid lines indicate the target water quality range (TWQR) and dashed lines indicate the chronic effect value (CEV) (DWAF, 1996).
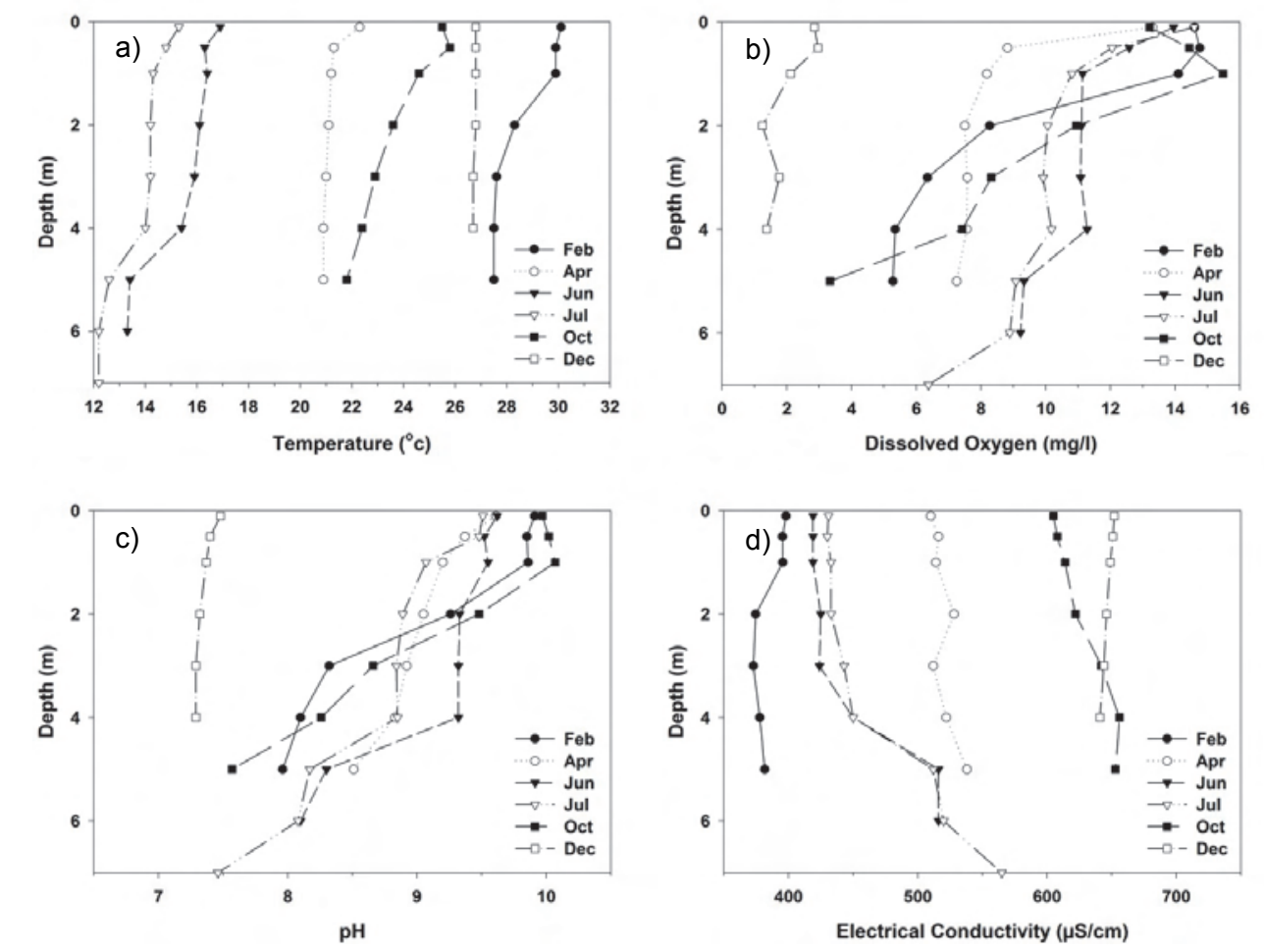

Figure 4

Field measurement profiles at Site LK2 in the transitional zone of Loskop Dam 

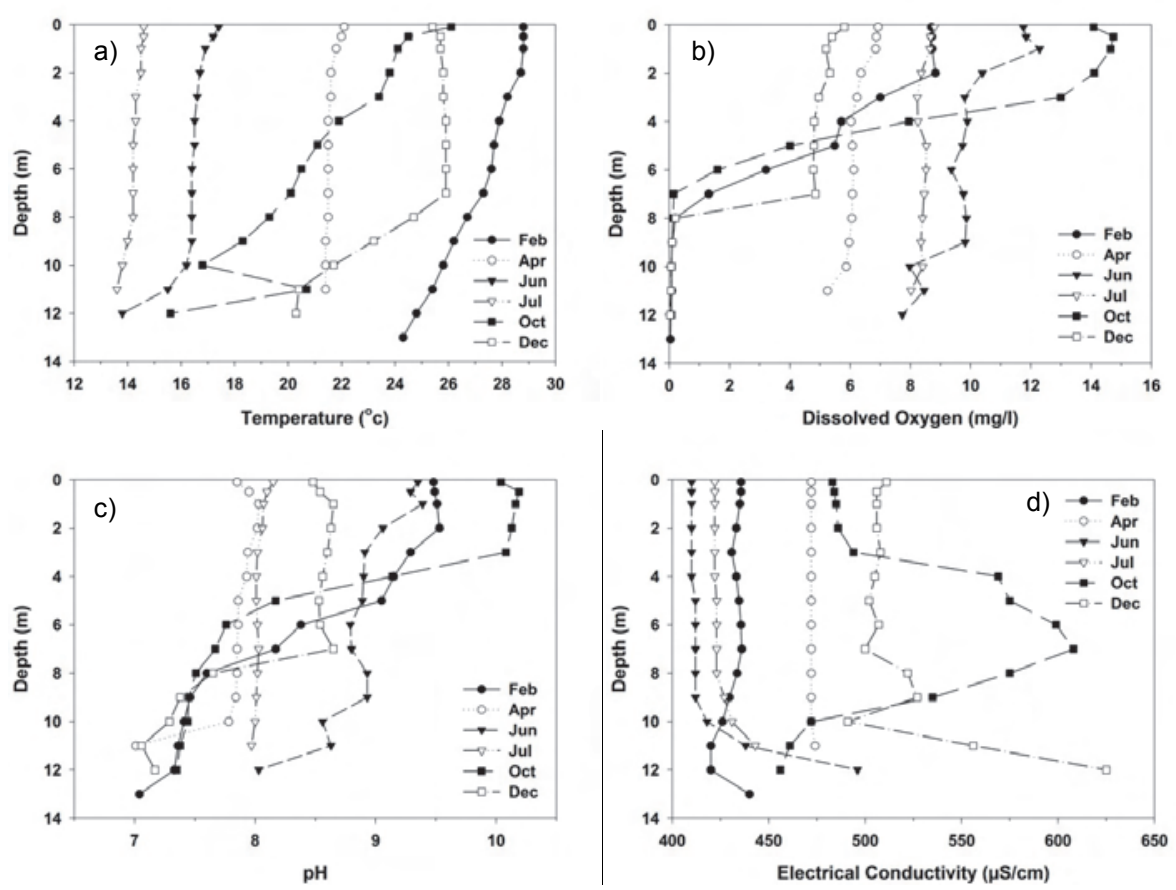

Figure 5

Field measurement profiles at Site LK3 in the transitional zone of Loskop Dam
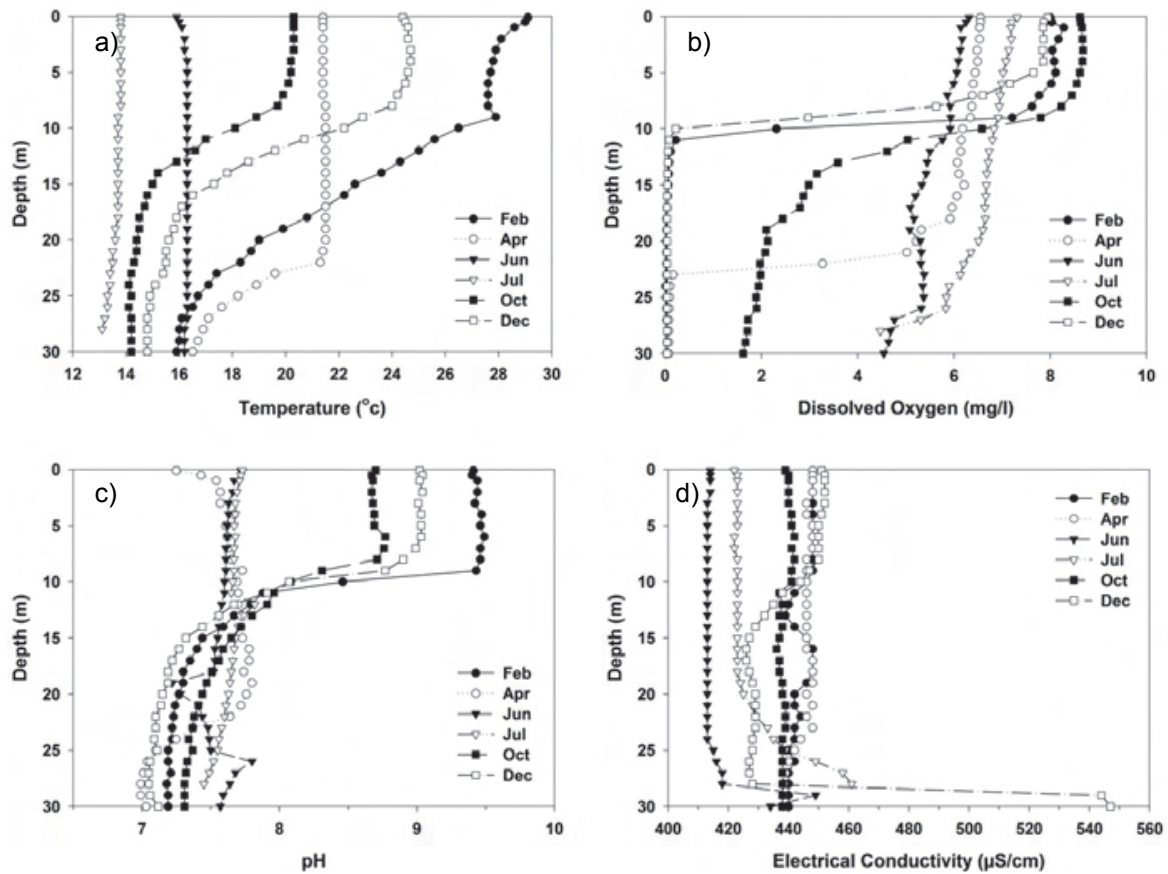

Figure 6

Field measurement profiles at Site LK5 near the dam wall in the lacustrine zone of Loskop Dam which is a tentative guideline (DWAF, 1996a). Given the lack of historic knowledge of Fe concentrations under unimpacted conditions in Loskop Dam, this complicates interpretation of the results. Iron followed a similar pattern to $\mathrm{Mn}$, with elevated concentrations observed in the near-bottom waters in December at all sites except the inflow at Site LK1, where there was little seasonal change or difference between surface and near-bottom concentrations (Fig. 3b). This indicates that fluctuating $\mathrm{Fe}$ and $\mathrm{Mn}$ concentrations are related to internal cycles within the dam.

Loskop Dam showed a monomictic pattern of thermal stratification in summer (October to April) and holomictic winter circulation (June to July). It was evident that although turnover had not yet occurred during monitoring in April, the water column was cooling towards winter isothermy as the thermocline deepened to $23 \mathrm{~m}$

(Fig. 6a). Temperatures declined rapidly with the water column cooling from $21.5^{\circ} \mathrm{C}$ in April to $16.5^{\circ} \mathrm{C}$ in June. Thermal stratification was already well developed in October, indicating that surface warming must have occurred earlier in August or September. Surface temperatures in summer were high, peaking in February at $>30^{\circ} \mathrm{C}$. Temperature profiles showed pronounced seasonal variability, with an annual thermal range of $>15^{\circ} \mathrm{C}$ in the upper $2 \mathrm{~m}$ of the water column (Figs. 4a, 5a, 6a).

Sites LK3 and LK5 demonstrated anoxic conditions in the hypolimnion with distinct oxyclines during December, while LK2 had very low dissolved oxygen ranging from $2.86 \mathrm{mg} / \ell$ at the surface to $1.38 \mathrm{mg} / \ell$ at the bottom. Anoxic conditions persisted at LK3 and LK5 in October and February, and at LK5 in April prior to lake overturn. Dissolved oxygen in the epilimnion at LK2 was frequently $>13 \mathrm{mg} / \ell$ and at LK3 was $>10 \mathrm{mg} / \ell$ in June and October which reflected the algal blooms at during December (Fig. 3c). Conditions in the hypolimnion during December at these sites were anoxic (Figs. 4, 5, 6), with a near-neutral $\mathrm{pH}$ and increased conductivity in the last $2 \mathrm{~m}$ of water above the dam bottom (Figs. $6 \mathrm{c}$ and d). In July the near-bottom concentrations exceeded the TWQR of $180 \mu \mathrm{g} / \ell$ at Site LK2, and the CEV at LK5, despite the water column being oxygenated at this time.

The TWQR for Fe stipulates that concentrations should not vary by more than $10 \%$ of the background concentrations, these sites (Fig. 4b). The $\mathrm{pH}$ followed a similar pattern to $\mathrm{DO}$ at LK2, with values $>9$ recorded in the upper 2-3 m every month except December (Fig. 4c).

Differences in the water chemistry profile of LK2 in July may have been driven by temperature. The water temperature was distinctly stratified, measuring $15.3^{\circ} \mathrm{C}$ at the surface and $12.2^{\circ} \mathrm{C}$ at $7 \mathrm{~m}$, a difference of $3.1^{\circ} \mathrm{C}$ with a thermocline between $4 \mathrm{~m}$ and $5 \mathrm{~m}$ (Fig. $4 \mathrm{a}$ ). The sub-surface water was similar in temperature to the inflow site $\mathrm{LK} 1$, at $11.7^{\circ} \mathrm{C}$, which implies 
that the cooler and denser river water submerged beneath the warmer surface waters of the dam before mixing. The conductivity at the surface was $431 \mu \mathrm{S} / \mathrm{cm}$, compared to $565 \mu \mathrm{S} / \mathrm{cm}$ at $7 \mathrm{~m}$ depth (Fig. $4 \mathrm{c}$ ), a difference of $134 \mu \mathrm{S} / \mathrm{cm}$ and more similar to the inflow measurement of $528 \mu \mathrm{S} / \mathrm{cm}$ (Table 2). Furthermore, near-bottom $\mathrm{SO}_{4}{ }^{2-}$ concentrations reflected riverine conditions at $185 \mathrm{mg} / \ell$ compared to $135 \mathrm{mg} / \ell$ in the surface water at LK2.

\section{Long-term trophic indicators}

Secchi disk measurements were only collected by DWA from 1990 to 1996; therefore the dataset was supplemented with values collected at LK5 as part of ongoing research conducted by the CSIR between 2008 and 2011. Most of the TSI values were in the mesotrophic range but phosphorus showed an upward trend into the eutrophic category from 2005 onwards, with a peak in 2008 (Fig. 7). This trend was not reflected in Secchi depth and chlorophyll- $a$ values which remained within the mesotrophic range throughout.

\section{Trend analysis}

Results of the Seasonal Mann-Kendall trend analyses are presented in Table 3. Scatterplots of selected parameters were presented with a LOWESS (Locally Weighted Scatterplot Smooth) trace in order to integrate results visually and clarify the data pattern. The time-series data for $\mathrm{pH}$ was non-monotonic, demonstrating downward and upward trends within the data range (Fig. 8a). From 1968 until the early 1980s pH values steadily decreased, then began to increase until around 1996 at which time they approximately levelled off. Overall the $\mathrm{pH}$ showed a significant increasing trend $(\mathrm{Tau}=0.375$; Table 3).

Electrical conductivity and the major ions all showed significant increases over time (Table 3). The $\mathrm{SO}_{4}^{2-}$ data had a generally monotonic distribution with a significant increasing trend $(\mathrm{Tau}=$ 0.694) that peaked in 2007 at around $160 \mathrm{mg} / \ell$, after which there was a slight decrease (Fig. 8b). While there was no clear trend in any direction in total nitrogen (Table 3), total phosphorus (Fig. 8c), showed a significant increasing trend ( Tau $=0.422$ ), with the highest levels observed in 2007 and especially 2008 at 0.128 $\mathrm{mg} / \ell$. Given the concern about algal blooms and the increasing trend in total phosphorus in Loskop Dam, the decreasing trend $(\mathrm{Tau}=-0.298)$ observed in chlorophyll- $a$ concentrations was unexpected (Table 3; Fig. 8d). However a very high proportion of the values were censored (46.7\%) and their inclusion in the calculation of quarterly medians for the trend analysis meant that occasional peaks were lost. The year 2008 also had the highest recorded value for chlorophyll- $a$ which was noteworthy because total phosphorus peaked at a similar time.

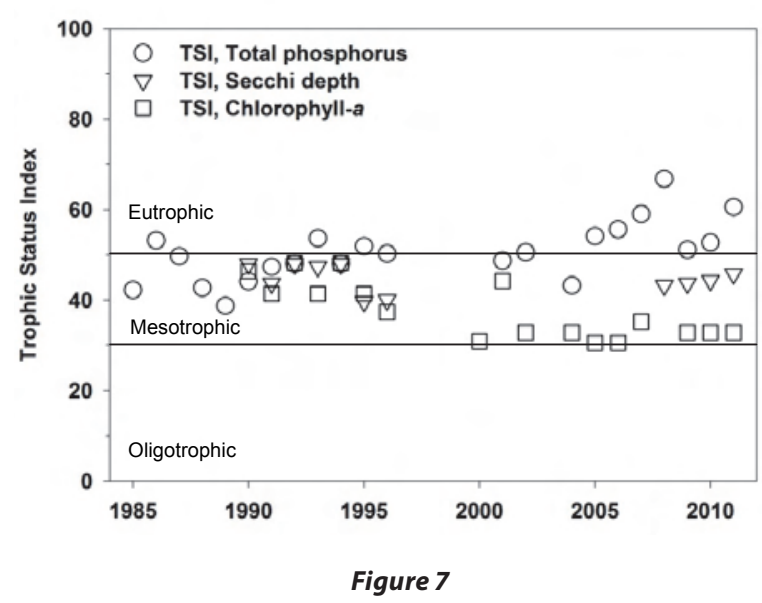

Trophic status index (TSI) calculated using the Carlson method (1977) for total phosphorus, secchi depth and chlorophyll-a using annual median values at Loskop Dam

The increasing trend in the sodium adsorption ratio is of concern as the primary use of the dam is for irrigation. However, the highest value recorded in the data range was 1.22 in 2011 which was still well within the TWQR of $<2$ according to the water quality guidelines for irrigation (DWAF, 1996b).

Trends could not be computed on all of the metals because of the high proportion of censored data and limited time period of data collection. Specifically, Al, Fe and Mn were only monitored sporadically from around 1991 with gaps as long as 10 years between samples. From around 2005 onwards, sampling occurred on a more regular basis, but for all three metals the number of censored values exceeded $50 \%$ and therefore trends were not computed.

The relationship between total phosphorus and dam level for the 10-year period between 2000 and 2010 is shown in

\begin{tabular}{|c|c|c|c|c|}
\hline \multicolumn{5}{|c|}{$\begin{array}{c}\text { TABLE } 3 \\
\text { Summary of seasonal Mann-Kendall trend analyses }\end{array}$} \\
\hline Parameter & Date range $(n)$ & $\begin{array}{c}\% \\
\begin{array}{c}\% \\
\text { Censored } \\
\text { data }\end{array} \\
\end{array}$ & Trend & $\begin{array}{l}\text { Kendall's } \\
\text { Tau }\end{array}$ \\
\hline $\mathrm{pH}$ (standard units) & $1968-2011(129)$ & 0 & + & $0.375^{* * *}$ \\
\hline $\mathrm{EC}(\mu \mathrm{S} / \mathrm{cm})$ & $1968-2011(130)$ & 0 & + & $0.734^{\star * *}$ \\
\hline Calcium $(\mathrm{mg} / \ell)$ & $1968-2011(129)$ & 0 & + & $0.696^{* * *}$ \\
\hline Magnesium (mg/l) & $1968-2011(129)$ & 0 & + & $0.708^{* * *}$ \\
\hline Potassium $(\mathrm{mg} / \mathrm{\ell})$ & $1972-2011(119)$ & 0 & + & $0.498^{* * *}$ \\
\hline Sodium $(\mathrm{mg} / \mathrm{\ell})$ & $1968-2011(128)$ & 0.8 & + & $0.415^{* * *}$ \\
\hline Sodium adsorption ratio & $1968-2011(128)$ & 0 & + & $0.351^{* * *}$ \\
\hline Chloride $(\mathrm{mg} / \ell)$ & $1968-2011(124)$ & 0 & + & $0.284^{* * *}$ \\
\hline Fluoride (mg/l) & $1972-2011(119)$ & 0.8 & + & $0.159^{*}$ \\
\hline Sulphate $(\mathrm{mg} / \ell)$ & $1968-2011(128)$ & 0 & + & $0.694^{* * *}$ \\
\hline Ryznar Index & $1976-2011(110)$ & 0 & - & $-0.665^{* * *}$ \\
\hline Total alkalinity as $\mathrm{CaCO}_{3}(\mathrm{mg} / \ell)$ & $1968-2011(129)$ & 0 & + & $0.264^{* * *}$ \\
\hline Total phosphorus (mg/l) & $1985-2011(80)$ & 3.8 & + & $0.422^{* * *}$ \\
\hline Total nitrogen $(\mathrm{mg} / \ell)$ & $1985-2011(78)$ & 6.4 & 0 & 0.038 \\
\hline Inorganic nitrogren $(\mathrm{mg} / \mathrm{l})$ & $1976-2011(114)$ & 44.7 & 0 & -0.065 \\
\hline Silica $(\mathrm{mg} / \ell)$ & $1976-2011(114)$ & 2.9 & - & $-0.209^{*}$ \\
\hline Chlorophyll- $a(\mu \mathrm{g} / \ell)$ & $1990-2011(60)$ & 46.7 & - & $-0.298^{*}$ \\
\hline
\end{tabular}

(+), upward trend; (-), downward trend; (0), no significant trend

Significance: ${ }^{* *},<0.0001 ; * *,<0.001 ; *,<0.05$ 

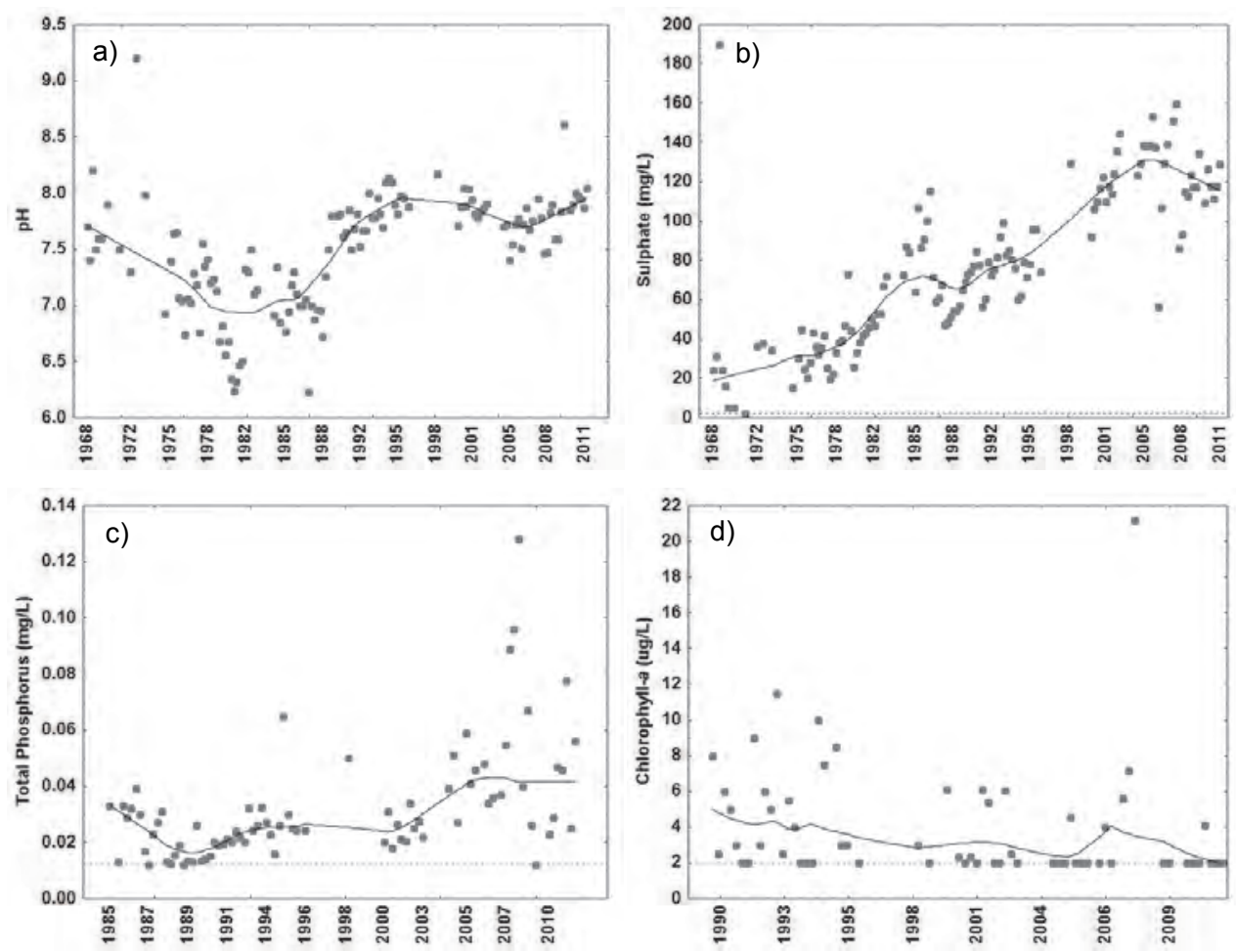

Figure 8

Seasonal Mann-Kendall trend test results with LOWESS smooth curves plotted for selected constituents. Dotted line indicates detection limits.

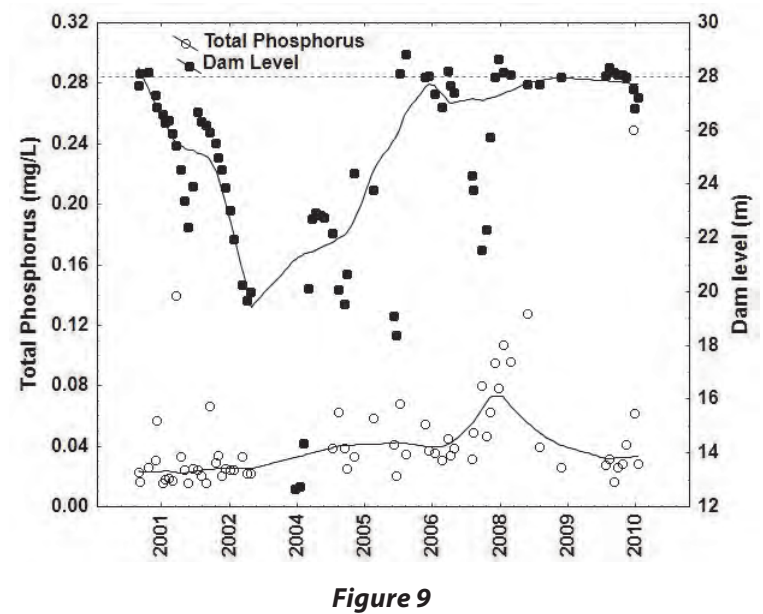

LOWESS smoothed scatterplot of total phosphorus concentrations and dam levels between 2000 and 2010. The dotted horizontal line indicates the gauge plate level at $28 \mathrm{~m}$ (full supply capacity).
Fig. 9. The dam level reduced drastically between 2001 and 2004, reaching a critical minimum of $12 \mathrm{~m}$ (24\% capacity) in January 2004 before beginning to increase from 2005 onwards. This event represented a $16 \mathrm{~m}$ drawdown which exposed significant areas of the littoral zone (Fig. 10). Corresponding total phosphorus concentrations appeared relatively stable before 2004, but increased steadily to a peak in 2008 , before decreasing to similar levels observed in 2005 and 2006.

\section{DISCUSSION}

There is a marked difference in water quality across Loskop Dam, largely influenced by the algal blooms that currently characterise the transitional zone. In this area, the system changes from one that supports organisms suited to lotic environments to one that supports those adapted to lentic environments, such as $M$. aeruginosa and C. hirundinella. During algal blooms, photosynthetic activity in daylight results in elevated $\mathrm{pH}(>9)$ through carbonic acid absorption, and increased dissolved oxygen levels $(>10 \mathrm{mg} / \ell)$ as a result of oxygen release. As blooms degrade, oxygen levels can plummet, as observed in December 2011 when dissolved oxygen dropped to $2.1 \mathrm{mg} / \ell$ in the surface water. The elevated $\mathrm{pH}$ levels can cause an increase in the concentration of the toxic un-ionised form of ammonia $\left(\mathrm{NH}_{3}\right)$ relative to the less toxic ammonium ion $\left(\mathrm{NH}_{4}^{+}\right)$(DWAF, 1996 ${ }^{\mathrm{a}}$ ). The solubility and bioavailability of $\mathrm{Al}$ is also increased at $\mathrm{pH}$ values $>8$ (Gensemer and Playle, 1999). All of these factors may negatively impact the health of aquatic biota, especially fish.

Through the use of algal assays, phosphate was reported as the limiting nutrient in Loskop Dam (Toerien et al., 1975), so the increasing trend in total phosphorus is a cause for concern. The revised mean retention time of 12.2 months is double the frequently referenced time of 6 months (Butty et al., 1980). The longer retention time and high shoreline development value increase the sensitivity of Loskop Dam to nutrient enrichment. a)

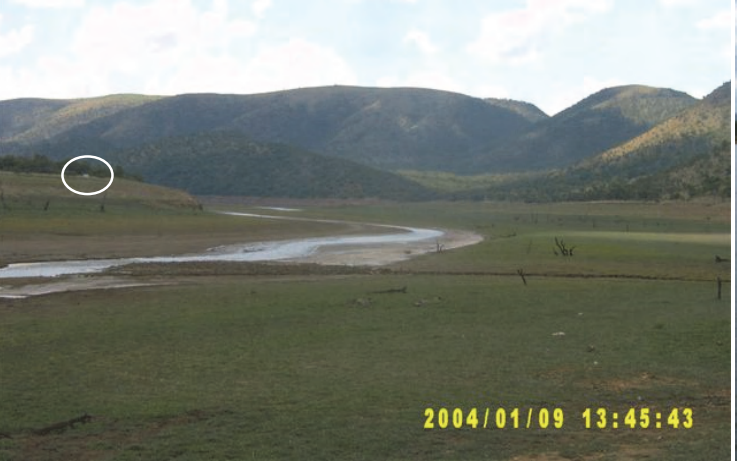

b)

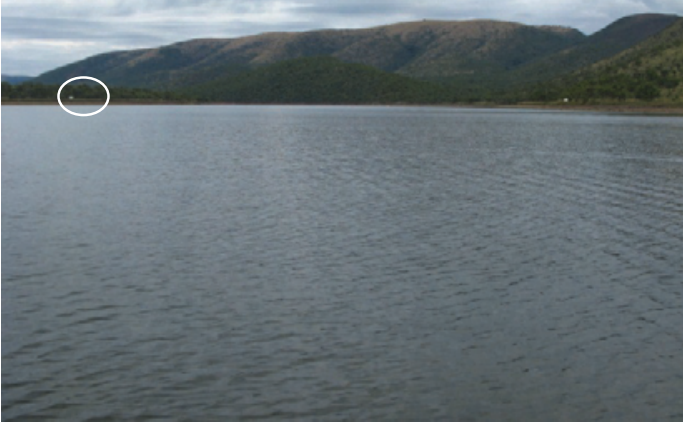

Figure 10

Picture taken near sampling site LK3 (notice board circled) when Loskop Dam was $24 \%$ full in 2004 (a), and at $100 \%$ full in 2011 (b) for comparison of water levels. (Fig. 10a courtesy Jannie Coetzee) 
However, the increased mean depth of $15.43 \mathrm{~m}$ offsets this sensitivity to a degree due to decreased mixing (Dodds and Whiles, 2010; Oberholster et al., 2013). The results of the TSI indicated that Loskop Dam was in the meso- to eutrophic category. However, the lack of agreement between all three indices suggests there may be other factors at play such as seasonal grazing of phytoplankton by zooplankton which would lower the Secchi depth and chlorophyll- $a$ TSI's. Another factor affecting the results is that a high proportion of the chlorophyll- $a$ data were censored, in which case the annual median value was often a censored value which excluded seasonal peaks associated with algal blooms.

What was clear from the data collected during 2011 was that the dam was heterogeneous with regard to nutrient concentrations, algal biomass and dissolved metals. Fluctuating concentrations of orthophosphate in the transitional zone, independent of the inflow, indicate internal phosphorus loading that may continue to stimulate algal blooms despite nutrient controls in the catchment. The shallow depth of this zone (4-7 m) may also play a role in the re-suspension of sediments with phosphorus due to wind mixing (Jones and Welch, 1990). Different zones in the dam display different eutrophication characteristics, and, for this reason, monitoring water quality at the dam wall alone may fail to detect changes at the onset of eutrophication. While internal phosphorus cycling from sediments has been shown to limit the recovery rates of phosphorus-enriched lakes (Van der Does et al., 1992), the borderline trophic classification of Loskop Dam suggests that a regime shift is incomplete and the dam may respond positively to decreased phosphorus loads in the catchment.

The convergent peaks of total phosphorus and chlorophyll$a$ in 2008 were intriguing and suggest an event of common origin. One explanation is linked to the dam level and rainfall patterns preceding 2010 . The dam level dropped substantially to $24 \%$ in January 2004 after below average annual rainfall (407.8 $\mathrm{m} \ell$ in 2002 and $351.5 \mathrm{~m} \ell$ in 2003) in the catchment. This period was followed by increasing rainfalls which culminated in a very high annual rainfall season in $2007(631.8 \mathrm{ml})$ and 2008 $(751.6 \mathrm{~m} \ell)$. Chlorophyll- $a$ measured $38.24 \mu \mathrm{g} / \ell$ in February 2008 , and the annual median total phosphorus approximately doubled from $0.048 \mathrm{mg} / \ell$ in 2007 to $0.089 \mathrm{mg} / \ell$ in 2008 , at which point the dam level was back to $103 \%$. The flushing rates of Loskop Dam are low, with a substantial hydraulic retention time of 12.2 months (Table 1), which increases its susceptibility to enhanced nutrient loadings (Vollenweider and Kerekes, 1980 ) and favours the establishment of inherently slow-growing species like C. hirundinella and M. aeruginosa (Reynolds et al., 2012). The large volume of rainfall from a nutrient-enriched catchment may have resulted in an extensive first flush which increased nutrient loads in the dam and stimulated the growth of algae. The first flush effect may have been enhanced by the reduced dilution capacity associated with very low dam levels at the time which resulted in high concentrations of nutrients. An alternative explanation may be linked to internal nutrient cycles. Lake drawdown is frequently used as an effective remediation technique for the control of macrophytes, but it has been known to result in algal blooms upon refilling as a result of nutrient release from re-wetted, organically enriched sediments (James et al., 2001).

Loskop Dam is a monomictic reservoir characterised by anaerobic conditions in the hypolimnion during a large portion of the year, until the autumn overturn which had begun to occur in April. The depth, intensity, and duration of hypolimnetic oxygen depletion has increased since profiles were recorded in previous studies in 1960 (Gieskes, 1960) and 1978 (Butty et al., 1980). This was probably due to the increased frequency and intensity of algal blooms that provide a significant source of organic matter. Bacterial decomposition of algal blooms exacerbates oxygen depletion, extending the depth and duration over which anoxic conditions occur. This is particularly significant at the sediment-water interface where oxygen consumption is most intense (Wetzel, 1983). Increasing inputs of organic matter and availability of $\mathrm{SO}_{4}^{2-}$ strongly influence the decomposition of organic matter through sulphate reduction in anaerobic environments (Holmer and Storkholm, 2001). This process increases the production of hydrogen sulphide which can be toxic to fish.

In addition, bottom water anoxia causes reducing conditions that release soluble $\mathrm{Fe}^{2+}$ and $\mathrm{Mn}^{2+}$ from bottom sediments (Wetzel, 1983), thus accounting for the elevated concentrations of dissolved $\mathrm{Fe}$ and $\mathrm{Mn}$ observed in the near-bottom water during 2011. Furthermore, the onset of anoxic conditions can cause the release of phosphorus from bottom sediments, further stimulating algal blooms by positive feedback (Nurnberg, 1984). In contrast, Al speciation is not redox sensitive (Gensemer and Playle, 1999) and therefore the elevated concentrations of dissolved $\mathrm{Al}$ observed at the near-bottom of LK2 and LK5 in December are unlikely to be attributed to anoxic conditions at these sites. The seasonal increase in $\mathrm{Al}$ above the TWQR in December may be linked to mine-water released through the controlled release scheme in the upper Olifants River catchment, which occurs during high flows. This is supported by the fact that the highest $\mathrm{SO}_{4}{ }^{2-}$ concentrations were also recorded at LK1 in October and December 2011. On a positive note, the recent decrease in sulphate concentrations observed in the trend analysis indicates that desalination efforts in the upper catchment may be having an impact (Mey and Van Niekerk, 2009). It is tempting to attribute the increasing trend in $\mathrm{pH}$ values observed in the early 1980s to treatment of acid mine drainage in the catchment, however the Brugspruit Mine Water Treatment plant near the town of Witbank was only constructed in 1995 (Mey and Van Niekerk, 2009) and therefore cannot account for this. The dam wall was raised by $9 \mathrm{~m}$ in 1980, which corresponds to the increase in $\mathrm{pH}$ and provides a possible explanation. The increased volume of the reservoir may have had a dilution effect on water significantly impacted by acid mine drainage.

The elevated concentrations of dissolved $\mathrm{Al}, \mathrm{Fe}$ and $\mathrm{Mn}$, above guideline levels, in the near-bottom water of Loskop Dam indicate a chemocline that warrants further monitoring. Potentially toxic dissolved metal concentrations may be restricted to the hypolimnion while the water column is stratified, but mixing associated with autumn turnover may temporarily increase their distribution in the water column. Therefore, profiles need to be taken more than twice in the year and at more frequent depth intervals to clarify the distribution of dissolved metals. Additional parameters should be measured such as redox, so that metal speciation can be modelled, and the processes influencing water chemistry in the hypolimnion can be delineated.

The occurrence of milky-blue coloured water, observed at Site LK1 in June, has also been observed further upstream on the Olifants River, below the confluence with the AMDimpacted Klipspruit (pers. obs.). The colour could be due to gypsum precipitation, which is a common by-product of lime neutralisation, and may originate from the Brugspruit Mine Water Treatment plant in the Klipspruit catchment. The blue colour may also be linked to aluminium precipitation 
as a result of neutralisation reactions in $\mathrm{pH}$-neutral waters (McCarthy and Pretorius, 2009). The fact that the plume of discoloured water reached the inflow of Loskop Dam is a strong indicator that the Klipspruit may significantly influence water quality. Dilution by the Olifants River and downstream Wilge River may at times be insufficient during low flows to mitigate the impact of the Klipspruit.

The lack of chemical equilibrium in the transitional zone of the reservoir presents fish with many physiological challenges as they may periodically be exposed to elevated levels of hydrogen sulphide, ammonia, and dissolved metals, as well as low dissolved oxygen. While these factors may result in acute fish kills and physiological stress, they have never been reported to cause symptoms associated with pansteatitis in O. mossambicus on their own. However, the combined effects of these factors on fish health have never been researched. An important piece in the pansteatitis puzzle is the increased frequency and extent of algal blooms, particularly in the transitional zone. From a fish health perspective, this represents a modified food web which may have important links to the development of pansteatitis in O. mossambicus, particularly as the disease is so often attributed to dietary causes (Fytianou et al., 2006). Generally O. mossambicus feed on a combination of detritus, phytoplankton, filamentous algae, diatoms and plant material (De Moor et al., 1985), but there are ontogenetic and site-specific differences which have not been researched in Loskop Dam. This is especially pertinent as previous research at Loskop Dam has reported elevated levels of $\mathrm{Al}$ and $\mathrm{Fe}$ in the stomach contents and body fat of O. mossambicus (Oberholster et al., 2011).

\section{CONCLUSION}

If the Olifants River is one of South Africa's hardest working rivers, Loskop Dam is surely one of South Africa's hardest working dams. However, its capacity to act as a repository for pollutants from the upper Olifants River catchment may be reaching a critical point, as indicated by reducing aquatic ecosystem health. Catchment management plans need to focus on reducing phosphorus inputs from point and nonpoint sources, and mitigating the impact of acid mine drainage from working and abandoned coal mines. Monitoring at the dam should be extended to include a second site in the transitional zone near LK2, and dissolved metal concentrations (especially $\mathrm{Al}, \mathrm{Fe}$ and $\mathrm{Mn}$ ) should be routinely measured. If the deteriorating environmental situation at Loskop Dam is allowed to continue unchecked there may be irreversible consequences for the aquatic ecosystem, such as the local extinction of crocodiles. The removal of whole trophic levels in conjunction with ongoing inputs of contaminants will increase the likelihood of a permanent regime shift to eutrophic conditions (Folke et al., 2004), which has serious implications for major water users.

\section{ACKNOWLEDGEMENTS}

The financial assistance of the National Research Foundation (NRF) towards this research is hereby acknowledged. Opinions expressed and conclusions arrived at, are those of the author and are not necessarily to be attributed to the NRF. Thanks to the Olifants River Forum for providing funding for this research. Field assistance from Andre Hoffman, Nico Lübcker and Morgan Trimble was invaluable and is sincerely appreciated. Dr Mike Silberbauer of the Department of Water Affairs is thanked for assistance obtaining data.

\section{REFERENCES}

APHA (AMERICAN PUBLIC HEALTH ASSOCIATION) (1998) Standard Methods for the Examination of Water and Wastewater (20 ${ }^{\text {th }}$ edn.). American Public Health Association (APHA), American Water Works Association (AWWA), and Water Pollution Control Federation (WPCF), Washington DC, USA.

BELL FG, BULLOCK SET, HALBICH TFJ and LINDSAY P (2001) Environmental impacts associated with an abandoned mine in the Witbank coalfield, South Africa. Int. J. Coal Geol. 45 195-216.

BELL FG, HALBICH TFJ and BULLOCK SET (2002) The effects of acid mine drainage from an old mine in the Witbank coalfield, South Africa. Q. J. Eng. Geol. Hydrogeol. 35 265-278.

BOTHA H, VAN HOVEN W and GUILLETTE LJ (2011) The decline of the Nile crocodile population in Loskop Dam, Olifants River, South Africa. Water SA 37 103-108.

BUTTY M, WALMSLEY RD and ALEXANDER CJ (1980) Loskop Dam. In: Walmsley RD and Butty M (eds.). The Limnology of Some Selected South African Impoundments. National Institute for Water Research, CSIR, Pretoria. 49-58.

CARLSON RE (1977) A trophic state index for lakes. Limnol. Oceanogr. 22 361-369.

COETZEE J (2011) Personal communication, 1 July 2011. Mr. J Coetzee, Regional Ecologist, Nkgala Region, Mpumalanga Tourism and Parks Agency, Private Bag X606, Groblersdal, 0470.

DE MOOR FC, WILKINSON RC and HERBST HM (1985) Food and feeding habits of Oreochromis mossambicus (Peters) in hypertrophic Hartbeespoort Dam, South Africa. S. Afr. J. Zool. 2 $170-176$.

DMR (DEPARTMENT OF MINERAL RESOURCES) (2009) Developments in the economic contribution of hydrocarbons, natural gas and coal. Report 78/2009. Directorate: Mineral Economics, Pretoria, South Africa.

DODDS W and WHILES M (2010) Freshwater Ecology. Concepts and Environmental Applications of Limnology ( $2^{\text {nd }}$ edn.). Elsevier, Burlington, USA.

DWAF (DEPARTMENT OF WATER AFFAIRS AND FORESTRY, SOUTH AFRICA) (1996a) South African Water Quality Guidelines. Vol. 7: Aquatic Ecosystems. Department of Water Affairs and Forestry, Pretoria, South Africa.

DWAF (DEPARTMENT OF WATER AFFAIRS AND FORESTRY, SOUTH AFRICA) (1996b) South African Water Quality Guidelines. Vol. 4: Agricultural Use: Irrigation. Department of Water Affairs and Forestry, Pretoria, South Africa.

DWAF (DEPARTMENT OF WATER AFFAIRS AND FORESTRY, SOUTH AFRICA) (2004) Olifants Water Management Area: Internal Strategic Perspective. Report PWMA, 04/0000/00/0304. Department of Water Affairs and Forestry, Pretoria, South Africa.

DWA (DEPARTMENT OF WATER AFFAIRS, SOUTH AFRICA) (2011) Green Drop Assessment Results 2010/11. Department of Water Affairs, Pretoria.

DWA (DEPARTMENT OF WATER AFFAIRS, SOUTH AFRICA) (2013) Hydrology. URL: 〈http://www.dwa.gov.za/sites.aspx> (Accessed 5 June 2013).

DE VILLIERS S and MKWELO ST (2009) Has monitoring failed the Olifants River, Mpumalanga? Water SA 35 (5) 671-676.

FERREIRA S and PIENAAR D (2011) Degradation of the crocodile population in the Olifants River gorge of Kruger National Park, South Africa. Aquatic Conserv: Mar. Freshwater Ecosyst. 21 155-164.

FOLKE C, CARPENTER S, WALKER B, SCHEFFER M, ELMQVIST T, GUNDERSON L and HOLLING CS (2004) Regime shifts, resilience, and biodiversity in ecosystem management. Annu. Rev. Ecol. Evol. Syst. 35 557-581.

FYTIANOU A, KOUTINAS AF, SARIDOMICHELAKIS MN and KOUTINAS CK (2006). Blood $\alpha$-Tocopherol, selenium and glutathione peroxidase changes and adipose tissue fatty acid changes in kittens with experimental steatitis (yellow fat disease). Biol. Trace Elem. Res. 112 131-143.

GENSEMER RW and PLAYLE RC (1999) The bioavailability and toxicity of aluminium in aquatic environments. Crit. Rev. Environ. Sci. Technol. 29 15-450. 
GIESKES J (1960) Part 2: Hydrobiological Survey of the Lake Loskop. National Institute of Water Research Project Report No.6/4h. National Institute of Water Research, Pretoria.

GOODWIN AE (2006) Steatitis, fin loss and skin ulcers of channel catfish, Ictalurus punctatus (Rafinesque), fingerlings fed salmonid diets. J. Fish Dis. 29 61-64.

HIRSCH RM, SLACK JR and SMITH RA (1982) Techniques of trend analysis for monthly water quality data. Water Resour. Res. 18 (1) 107-121.

HOLMER M and STORKHOLM P (2001) Sulphate reduction and sulphur cycling in lake sediments: a review. Freshwater Biol. 46 431-451.

HUCHZERMEYER KDA, GOVENDER D, PIENAAR D and DEACON AR (2011) Steatitis in wild sharptooth catfish, Clarius gariepinus (Burchell), in the Olifants and lower Letaba Rivers in the Kruger National Park, South Africa. J. Fish Dis. 34 489-498.

JAMES WF, BARKO JW, EAKIN HL and HELSEL DR (2001) Changes in sediment characteristics following drawdown of Big Muskego Lake, Wisconsin. Fundam. Appl. Limnol. 151 459-474.

JONES CA and WELCH EB (1990) Internal phosphorus loading related to mixing and dilution in a dentritic, shallow prairie lake. Res. J. Water Pollut. Control Fed. 62 847-852.

LARSEN RE (1983) Steatitis and fat necrosis in captive alligators. J. Am. Vet. Med. Assoc. 183 (11) 1202-1204.

McCARTHY TS and PRETORIUS K (2009) Coal mining on the Highveld and its implications for future water quality in the Vaal River system. Abstracts of the International Mine Water Conference, 19-23 October 2009, Pretoria.

MEY WS and VAN NIEKERK AM (2009) Evolution of mine water management in the Highveld coalfields. Abstracts of the International Mine Water Conference, 19-23 October, Pretoria.

MIDGLEY DC, PITMAN WV and MIDDLETON BJ (1994) Surface Water Resources of South Africa 1990. Appendices, $1^{\text {st }}$ edn. WRC Report No. 298/1/94. Water Research Commission. Pretoria.

MUCINA L and RUTHERFORD MC (2006) The Vegetation of South Africa, Lesotho and Swaziland. Strelitzia 19. South African National Biodiversity Institute (SANBI), Pretoria, South Africa.

NURNBERG GK (1984) The prediction of internal phosphorus loads in lakes with anoxic hypolimnia. Limnol. Oceanogr. 29 111-124.

OBERHOLSTER PJ, MYBURGH JG, ASHTON PJ and BOTHA A-M (2010) Responses of phytoplankton upon exposure to a mixture of acid mine drainage and high levels of nutrient pollution in Lake Loskop, South Africa. Ecotoxicol. Environ. Saf. 73 326-335.

OBERHOLSTER PJ and BOTHA A-M (2011) Dynamics of phytoplankton and phytobenthos in Lake Loskop (South Africa) and downstream irrigation canals. Fundam. Appl. Limnol. 179 169-178.

OBERHOLSTER PJ, MYBURGH JG, ASHTON PJ, COETZEE JJ and BOTHA A-M (2012) Bioaccumulation of aluminium and iron in the food chain of Lake Loskop, South Africa. Ecotoxicol. Environ. Saf. 75 134-141.
OBERHOLSTER PJ, DABROWSKI J and BOTHA A-M (2013) Using modified multiple phosphorus sensitivity indices for mitigation and management of phosphorus loads on a catchment level. Fundam. Appl. Limnol. 182 1-16.

PINETOWN KL, WARD CR and VAN DER WESTHUIZEN WA (2007) Quantitative evaluation of minerals in coal deposits in the Witbank and Highveld Coalfields, and the potential impact on acid mine drainage. Int. J. Coal Geol. 70 166-183.

PORRA RJ, THOMPSON WA and KRIEDEMANN PE (1989) Determination of accurate extinction coefficients and simultaneous equations for assaying chlorophylls a and b extracted with four different solvents: verification of the concentration of chlorophyll standards by atomic absorption spectrometry. Biochim. Biophys. Acta 975 384-394.

REYNOLDS CS, MABERLY SC, PARKER JE and DE VILLE MM (2012) Forty years of monitoring water quality in Grasmere (English Lake District): separating the effects of enrichment by treated sewage and hydraulic flushing on phytoplankton ecology. Freshwater Biol. 57 384-399.

ROBERTS RJ, RICHARDS RH and BULLOCK AM (1979) Pansteatitis in rainbow trout Salmo gairdneri Richardson: A clinical and histopathological study. J. Fish Dis. 2 85-92.

ROBERTS RJ and AGIUS C (2008) Pansteatitis in farmed northern bluefin tuna, Thunnus thynnus (L.), in the eastern Adriatic. J. Fish Dis. 31 83-88.

STEVENS MR (2003) Water quality and trend analysis of Colorado - Big Thompson System reservoirs and related conveyances, 1969 through 2000. U.S. Geological Survey, water resources investigations report 03-4044. United States Geological Survey, Reston, Virginia.

TIMMS B (2010) Geomorphology of Lake Basins. In: Likens GE (ed.) Lake Ecosystem Ecology. Academic Press, San Diego. 203 pp.

TOERIEN DF, HYMAN KL and BRUWER MJ (1975) A preliminary trophic status classification system of some South African impoundments. Water SA 1 15-23.

VAN DER DOES J, VERSTRAELEN P, BOERS P, VAN ROESTEL J ROIJACKERS R and MOSER G (1992) Lake restoration with and without dredging of phosphorus-enriched upper sediment layers. Hydrobiologia 233 (1-3) 197-210.

VAN VUUREN L (2008) Loskop Dam - Early local engineering ingenuity. The Water Wheel 7 (5) 18-21.

VAN VUUREN L (2009) Experts unite to save abused river from extinction. The Water Wheel 8 (1) 14-17.

VERMUELEN PD and USHER BH (2006) Sulphate generation in South African underground and opencast collieries. Environ. Geol. $49552-569$

VOLLENWEIDER RA and KEREKES J (1980) The loading concept as a basis for controlling eutrophication philosophy and preliminary results of the OECD programme on eutrophication. Prog. Water Technol. 12 5-38.

WETZEL RG (1983) Limnology (2 ${ }^{\text {nd }}$ edn.). Saunders College Publishing, Orlando, USA. 